NBER WORKING PAPER SERIES

\title{
THE HIDDEN RESOURCES OF WOMEN WORKING LONGER: EVIDENCE FROM LINKED SURVEY-ADMINISTRATIVE DATA
}

\author{
C. Adam Bee \\ Joshua Mitchell \\ Working Paper 22970 \\ http://www.nber.org/papers/w22970 \\ NATIONAL BUREAU OF ECONOMIC RESEARCH \\ 1050 Massachusetts Avenue \\ Cambridge, MA 02138 \\ December 2016
}

The views expressed herein are those of the authors and do not necessarily reflect the views of the US Census Bureau or NBER. We would like to thank Courtney Coile, Claudia Goldin, Larry Katz, and the other Women Working Longer conference participants for providing feedback and guidance. We would also like to thank Jon Rothbaum and Trudi Renwick at Census for their support. For the Survey of Income and Program Participation (SIPP) Gold Standard File, we thank Gary Benedetto and Lori Reeder at Census for their assistance and patience. All results have been formally reviewed to ensure that no confidential Census Bureau data have been disclosed. The views expressed herein are those of the authors and do not necessarily reflect the views of the National Bureau of Economic Research.

NBER working papers are circulated for discussion and comment purposes. They have not been peer-reviewed or been subject to the review by the NBER Board of Directors that accompanies official NBER publications.

(C) 2016 by C. Adam Bee and Joshua Mitchell. All rights reserved. Short sections of text, not to exceed two paragraphs, may be quoted without explicit permission provided that full credit, including $(\odot$ notice, is given to the source. 
The Hidden Resources of Women Working Longer: Evidence from Linked SurveyAdministrative Data

C. Adam Bee and Joshua Mitchell

NBER Working Paper No. 22970

December 2016

JEL No. D14,D91,H55,J14,J26

\begin{abstract}
Despite women's increased labor force attachment over the lifecycle, household surveys such as the Current Population Survey Annual Social and Economic Supplement (CPS ASEC) do not show increases in retirement income (pensions, 401(k)s, IRAs) for women at older ages. We use linked survey-administrative data to demonstrate that retirement incomes are considerably underreported in the CPS ASEC and that women's economic progress at older ages has been substantially understated over the last quarter century. Specifically, the CPS ASEC shows median household income for women age 65-69 rose 21 percent since the late 1980s, while the administrative records show an increase of 58 percent. Survey biases in women's own incomes appear largest for women with the longest work histories. We also exploit the panel dimension of our data to follow a cohort of women and their spouses (if present) as they transition into retirement in recent years. In contrast to previous work, we find that most women do not experience noticeable drops in income up to five years after claiming social security, with retirement income playing an important role in maintaining their overall standard of living. Our results pose a challenge to the literature on the "retirement consumption puzzle" and suggest total income replacement rates are high for recent retirees.
\end{abstract}

C. Adam Bee

US Census Bureau

Charles.Adam.Bee@census.gov

Joshua Mitchell

US Census Bureau

joshua.w.mitchell@ census.gov 


\section{Introduction}

We begin with a puzzle. Why has the dramatic rise in female lifecycle labor force participation not been accompanied by an increase in retirement income for women at older ages?

The basis for this puzzle is the Current Population Survey Annual Social and Economic Supplement (CPS ASEC), the source of the nation's official income and poverty statistics. We use it to plot in Figure 1 the rate of retirement income receipt for women age 65 to 69 and age 70 to 74 between 1987 and $2012 .{ }^{1}$ As we will discuss in more detail, our measure of retirement income also includes survivor and disability income but excludes all payments from social security and veterans benefits. (The sample in Figure 1 is further restricted to women who also report receiving social security income to focus attention on women who are very likely to be retired.) For both women age 65 to 69 and age 70 to 74, it is remarkable how little retirement income receipt has apparently changed in 25 years. The rate of receipt fluctuates within a band of about 7 percentage points, and it never exceeds 34 percent.

The lack of any measurable trend comes in spite of many changes during working years that one might think would alter the trajectory of retirement income, particularly for women. More recent cohorts of women are attached to the labor force for longer periods of time (Goldin and Mitchell, forthcoming), are more likely to have careers rather than just jobs (Goldin, 2006), are more likely to graduate from college (Goldin et al., 2006), and are paid at higher rates relative to men (DeNavas-Walt and Proctor, 2015). So why would they not be more likely to have a pension, a 401(k), or an IRA?

\footnotetext{
${ }^{1}$ For survey years prior to the 1988, our CPS ASEC files do not allow us to define retirement income in a way that is fully consistent with the 1987 to 2012 reference year period. In 2014, the CPS ASEC underwent a major redesign that altered thequestions relating to retirement income. See Semega and Welniak(2015) and Mitchell and Renwick (2015) for more details.
} 
We use linked survey-administrative data to argue that surveys such as the CPS ASEC are increasingly failing to capture much of the retirement income received by women, and this omission has significant implications for understanding their material well-being in retirement. We do not mean to suggest that underreporting is unique to women. In fact, in related work (Bee and Mitchell, in progress), we provide in-depth analysis of underreporting and its causes for the entire population age 65 and older. However, in keeping with the theme of this volume, we choose to focus exclusively on women born from the early 1920s to the late 1940s and draw out implications of their increasing labor force attachment across successive birth cohorts.

Our main contribution is to highlight that to the extent underreporting is a growing problem, household surveys will fail to reflect the full consequences of women working longer and understate the economic progress of women at older ages. We show that underreporting not only biases trends in income across cohorts but also distorts the relationship between career work experience and retirement income within a given cohort. Lastly, we show that for recently retired women, accurate measures of retirement income are crucial for understanding the transition to retirement. In contrast to previous work, we find very little evidence of total household income falling for most women as they and their spouses (if present) withdraw from the labor market and begin to receive social security. ${ }^{2}$ Our finding poses a challenge to the literature on the "retirement consumption puzzle" which seeks to explain household consumption behavior under the assumption that incomes are falling predictably at retirement.

We should note that concerns about measuring retirement income in the CPS ASEC are not new (Czajka and Denmead, 2012). Conceptually, the CPS ASEC aims to capture money income, or a stream of regular payments. This accounting fits naturally with traditional defined

\footnotetext{
${ }^{2}$ Using panel taxdata, Brady et al. (in progress) also find little evidence of an income drop at retirement.
} 
benefit pension plans, which typically provide annuity income, but it is more challenging to reconcile with defined contribution (DC) retirement plans, where withdrawals are often done on an as-needed basis. Partly in response to the changing retirement landscape, the CPS ASEC underwent a major redesign in 2014. That design change was intended to provide more accurate information on income from defined contribution plans (Mitchell and Renwick, 2015; Semega and Welniak, 2015). For our purposes, we will consider both annuities and retirement account withdrawals as income but note that many of the cohorts of women examined in this paper are likely to have only defined benefit income.

We begin in section II by briefly reviewing the relevant literature. We next describe the construction of our newly linked survey-administrative dataset in section III. In section IV, we document trends in work, social security and retirement income for successive cohorts of women born between the early 1920s and the late 1940s. In section V, we compare CPS self-reports with administrative records to demonstrate growing retirement income underreporting rates across birth cohorts and the consequences for measuring women's total incomes. In section VI, we explore the relationship between years of work experience and bias in retirement income measurement for women born in the late 1940s. In section VII, we examine incomes for women and their spouses (if present) as they transition to retirement. Section VIII concludes.

\section{Prior Work}

The literature on measuring income and well-being in surveys is vast and we do not attempt an exhaustive review here. Studies most related to our paper reassess the well-being of the aged in retirement. Cutler and Katz (1991), Hurd and Rohwedder (2006), and Meyer and Sullivan (2010, 2012) compare consumption- and income-based measures of poverty and find evidence of considerably more economic progress for the aged when using consumption 
measures. The lifecycle model motivates a focus on consumption because consumption is more closely connected to long-run economic status. Consumption may also be preferable if certain types of income are difficult for survey respondents to report. We contribute to the above studies by uncovering substantial underreporting of retirement income for women using administrative records. Our findings thereby help reconcile the differences found between survey-based measures of consumption and income for the aged.

Beyond measuring income and consumption at points in time, our findings also relate to longitudinal studies that examine changes in well-being over time, especially as households transition into retirement. A number of prominent studies such as Banks et al. (1998) and Bernheim et al. (2001) have noted that consumption appears to fall sharply at retirement. Because the standard lifecycle model predicts that forward-looking households should be able to smooth consumption in response to anticipated declines in income, this apparent empirical violation gives rise to the "retirement consumption puzzle" and is taken as evidence that households are myopic and inadequately prepared for retirement. More recent studies have questioned this initial conclusion.

Hurst (2008) surveys the recent literature and finds that it is mainly work and food expenditures that decline while recreational spending and donations to charity actually increase. Moreover, the decline in food expenditures is offset by an increase in home production and an increase in shopping for grocery bargains such that actual food consumption does not fall (Aguiar and Hurst, 2005 and 2007). Although we do not measure consumption directly, our findings challenge the premise that income falls for most households in retirement. Our administrative record measure of retirement income plays an important role in obtaining this result. Even though the composition of consumption may change at retirement, we show that it is 
not possible to test the lifecycle model against alternatives when annual incomes remain steady, at least for a cohort of recently retired women.

Lastly, our use of administrative records to validate survey responses contributes to the large literature on survey measurement error. With the exception of our work in Bee (2013) and Bee and Mitchell (in progress), few studies have been able to validate retirement income directly. Studies reviewed in Munnell and Chen (2014) compare survey aggregates to outside sources such as the National Income and Product Accounts or SOI tax tables (which exclude non-filers) and conclude that the CPS ASEC is missing substantial amounts of retirement income, usually with an emphasis on income from defined contribution accounts. But without the ability to link survey and administrative data, the distributional implications of underreported retirement income remain strongly disputed. For the cohorts of women examined, we show that correcting for underreporting does in fact have broad distributional consequences.

Other studies do address survey measurement error with respect to pensions and retirement accounts but focus on current workers, comparing survey responses to employerprovided plan descriptions (Gustman et al., 2010; Mitchell, 1988). These studies reveal that workers in general do not understand key features of pension plans such as early retirement options and the distinction between defined benefit and defined contribution systems. Workers also have trouble reporting participation in defined contribution plans and the amount of their contributions (Dushi and Honig, 2015; Dushi and Iams, 2010). A lack of financial literacy may hinder the gathering of accurate information on retirement preparation (Lusardi and Mitchell, 2014 and this volume). It may also provide clues as to why underreporting of incomes in retirement appears to be a significant problem. 


\section{Data and Methods}

We construct a novel dataset that links survey data with several administrative record sources. For most of our analysis, the underlying samples are drawn from the Survey of Income and Program Participation (SIPP). The SIPP is a series of nationally representative samples of households interviewed over a multi-year period. We use the first waves of the 1984, 1990, 1996, 2001, 2004, and 2008 SIPP panels. We use a harmonized version of the SIPP known as the Gold Standard File. ${ }^{3}$ Because we are only using a single wave from each panel, we are treating the SIPP data as a series of cross-sections, drawing mainly demographic and household relationship information from the SIPP. The longitudinal dimension of our analysis comes exclusively from the administrative records with the advantage that we can follow our SIPP samples forwards and backwards in time without attrition.

We do not use income data directly from the SIPP because SIPP income data are collected for a four-month reference period that does not correspond to calendar year information available in several of our administrative record sources. Instead, we compare annual income from the linked administrative records to standalone data from the CPS ASEC.

As mentioned above, the CPS ASEC is the source of the nation's official income and poverty statistics. Between February and April of each year, the CPS ASEC surveys a nationally representative sample of approximately 75,000 households and ascertains income types and annual amounts for the previous calendar year. We are particularly interested in the extent to which retirement income is underreported in the CPS ASEC and how that may bias our

\footnotetext{
${ }^{3}$ Data from the SIPP Gold Standard File are confidential. All results have been formally reviewed to ensure that no confidential Census Bureau data have been disclosed.
} 
assessment of women's well-being at older ages. The CPS ASEC asks the following question for each member of the household related to retirement income:

"Other than social security or VA benefits, did ... receive any pension or retirement income?”

If the response is affirmative, then follow-up questions elicit the amount and source of income. There are two analogous sets of questions about survivor income and disability income outside of Social Security and VA benefits. We aggregate responses to all three questions in our definition of retirement income.

We choose to use the linked SIPP data rather than the linked CPS ASEC for most of our analysis because the linked SIPP data are available further back in time and allow us to examine earlier cohorts of women. Furthermore, the SIPP data tend to have higher linkage rates. ${ }^{4}$ But when we examine the most recent birth cohort of women in their older ages in section VI, we need to use the linked 2013 CPS ASEC rather than the SIPP.

Our administrative records allow us to examine five types of income that are particularly important at older ages: earnings (both wages and self-employment), social security benefits, Supplemental Security Income (SSI), interest and dividends, and retirement income. Data on earnings, social security benefits, and SSI are obtained from the Social Security Administration (SSA). Data on taxable and tax-exempt interest and dividends come from IRS Form 1040 records. Not everyone files a 1040 in a given year, but we can assume that those with more than

\footnotetext{
${ }^{4}$ SIPP and CPS ASEC data are assigned a Personal Identification Key (PIK), which is a confidentiality-protected vers ion of a social security number. The PIK allows the survey data to be linked to the adminis trative records. See Wagner and Layne(2014) for more details. Linkage rates vary across each survey but are generally in the high 80 percent range. In order to account for any differences between the PIK subsample and the overall sample, we run for each survey a logit model using demographic information to predict the assignment of a PIK and calculate an estimated propensity score. Then we multiply the survey weight by the inverse of the estimated propensity score.
} 
minimal amounts of capital income would be required to file.

Lastly, retirement income data come from two sources, and are available regardless of whether or not an individual filed a tax return in a given year. We have discovered data from Form W-2P “Statements for Recipients of Annuities, Pensions, Retired Pay or IRA payments,” in SSA administrative records for years 1978 to 1990. These records contain periodic payments and withdrawals but exclude rollovers and other total distributions that are best thought of as moving money from one retirement account to another. After 1990, Form W-2P was merged with IRS Form 1099-R, “Distributions From Pensions, Annuities, Retirement or Profit-Sharing Plans, IRAs, Insurance Contracts, etc.” We have obtained from IRS the 1099-R information returns from 1995 onward. Our version of the 1099-R extracts also excludes direct rollovers and other transactions we would not wish to consider as increasing the resources available to women in retirement. In short, we have reliable and reasonably consistent retirement income data spanning 1978 to 1990 and 1995 onward. These data allow us to examine long-run trends in underreporting of retirement income in the CPS ASEC.

From each linked survey, we draw a five-year birth cohort group of women such that they are in their sixties when interviewed. Across all linked surveys, we cover women born from the early 1920s to the late 1940s. The women in our sample are either the householder or spouse of the householder. Lastly, for tracking incomes over time, we often require that women survive until age 70 to maintain a balanced panel. All income amounts are adjusted for inflation using the CPI-U-RS and are expressed in 2012 dollars. 
Summary statistics for each of the six birth cohorts groups are shown in Table 1 along with approximate sample sizes. Across cohorts, college graduation rates have more than doubled while the share of women who are currently married has declined slightly.

\section{Cohort-Age Patterns}

\section{A. Employment}

We first describe patterns of work at older ages for women born between 1921 and 1948. Throughout our analysis, employment is defined as having annual administrative earnings (both W-2 wages and self-employment) of at least the prevailing year's hourly federal minimum wage times ten hours per week times 52 weeks per year, as in Goldin and Katz (this volume). Figure 2 plots employment rates for five-year birth cohort groups between ages 55 and 70 . Because our earnings records extend from 1978 until 2012 we are unable to observe the earliest and the latest cohorts at extreme ages. Nevertheless, a clear pattern emerges.

Consistent with the theme of this volume, women are working longer-the entire employment path for a more recent cohort is generally above the employment path of previous cohorts. Among women born between 1921 and 1925 (the earliest cohort), only 46 percent worked at age 57. In contrast, for women born between 1944 and 1948 (the most recent cohort) the employment rate at age 57 was 61 percent. The same pattern holds when women are in their sixties. At age 64, 24 percent of women born between 1921 and 1925 were working compared with 39 percent for women born between 1944 and 1948. These employment patterns provide supporting evidence for the hypothesis that more recent cohorts of women are attached to the workforce longer and therefore are more likely to be eligible for a pension, and in recent years, are more likely to be able to make contributions to an employer-sponsored DC plan or to an IRA. 
We explore how changing demographic characteristics of women affect cohort employment patterns in Table 2. We run linear probability models for work on a full set of age fixed effects covering the age ranges where we have a balanced panel across cohorts. We examine the cohort group coefficients (the 1921 to 1925 cohort is the omitted group) and compare their magnitudes to a second specification where we control for five categories of educational attainment-high school dropout (omitted), high school graduate, some college, college graduate, and advanced degree - and five categories of marital status — never married (omitted), married, widowed, divorced, and separated. Not surprisingly, higher levels of educational attainment are strongly associated with labor force attachment. Married, widowed, and separated women are about 13 to 16 percentage points less likely to work than never-married women, all else equal. The coefficients on the later cohorts are somewhat muted after controlling for education and marital status, indicating that some of the trend toward working longer reflects greater educational attainment and reduced marriage, but there are still important cohort effects for women born in the 1930s and 1940s. ${ }^{5}$

\section{B. Social Security Receipt}

Figure 3 describes the age pattern of social security income receipt across cohorts. Social security receipt is defined as having any positive amount of annual OASDI benefits in the administrative records. At pre-retirement ages, more recent cohorts are actually somewhat more likely to receive social security than are earlier cohorts. This difference reflects the fact that more recent cohorts of women are more likely to be eligible for social security disability insurance (SSDI) due to their longer earnings histories and also because the medical examination process has become more relaxed (Autor and Duggan, 2006). Starting at age 62, and for those below

\footnotetext{
${ }^{5}$ Note this is an earlier set of birth cohorts than those in the HRS examined by Goldin and Katz (this volume).
} 
what is known at the "full retirement age," reduced social security retirement benefits are available. ${ }^{6}$ The most recent cohorts of women are less likely to claim social security retirement benefits before full retirement age. For example, at age 64, 77 percent of women born between 1921 and 1925 received social security benefits but only 62 percent of women born between 1944 and 1948 did. Thus, women are working longer and also claiming social security later.

Columns 3 and 4 of Table 2 explore regression results for social security receipt during early retirement years-ages 62 to 64 . Higher educated women are less likely to claim social security early. Not surprisingly, widows are 26 percentage points more likely to be receiving social security benefits than never-married women, all else equal. The cohort effects start declining for women born in the 1930s and turn sharply negative for the 1944 to 1948 birth cohorts. Adding controls for education and marital status produces cohort effects that are more strongly positive, with a smaller drop for the 1944 to 1948 birth cohorts.

\section{Retirement Income Receipt}

Estimates of retirement income receipt from SSA and IRS administrative records are shown in Figure 4. Recall that annual amounts of pension and annuity income as well as periodic withdrawals from employer-sponsored DC accounts and IRAs are included in the definition of retirement income. Transactions that move money from one retirement account to another, such as rollovers and conversions, are excluded. Also important is that we observe receipt of retirement income but not the reason for receipt. Some women may be receiving survivor income that reflects their deceased spouses' earnings histories rather than their own, although that is less likely at younger ages. Note that data age gaps in Figure 4 reflect the time period between 1991

\footnotetext{
${ }^{6}$ The full retirement age is 65 for individuals born before 1938. After 1938, the full retirement age is gradually increas ed until it reaches 67 for those born after 1959. See https://www.ssa.gov/planners/retire/retirechart.html.
} 
and 1994 during which we do not have retirement income data for all members of a cohort group. Nevertheless, the combined series provides novel evidence of an important component of women's total retirement resources spanning over three decades.

Rates of retirement income receipt rise substantially with age, for example, from 23 percent to 52 percent for the 1937 to 1941 cohort between ages 60 and 70 . Rates also rise across cohorts. At age 60, the 1921 to 1925 cohort had a rate of receipt of 11 percent while the 1944 to 1948 cohort had a rate of receipt of 29 percent.

These results provide preliminary evidence that is in stark contrast to the CPS ASEC numbers shown in Figure 1. While retirement income receipt at advanced ages never exceeds 34 percent in the CPS ASEC (even conditioning on those receiving social security), the administrative data indicate that no cohort observable at age 70 has a rate of receipt lower than 50 percent. We will provide more direct evidence of underreporting in section V.

Regression results confirm that educational attainment strongly predicts retirement income receipt. Widowed women are also more likely than other groups to have retirement income, which would likely include survivor pension income. For recent observable cohorts, the rates of receipt between ages 59 and 64 remain about 11 percentage points higher relative to the 1921 to 1925 birth cohorts, after controlling for educational attainment and marital status.

\section{Cross-Cohort Patterns in Underreporting}

We now turn to survey underreporting across calendar years and its implication for measuring the incomes of women across cohorts. Our analysis draws on a series of crosssections based on linked SIPP-administrative data. We compare these administrative measures of income to the standalone CPS ASEC measures. Table 3 illustrates the extent of underreporting in 
1984, 1989, 1995, 2000, 2003, and 2007. We select women from each survey when they are ages 65 to 69 . The first rows compare social security receipt and median benefit amounts in the linked data and the CPS ASEC. Across all years, there is a very close correspondence of both receipt and benefit amounts. The discrepancy in receipt is not more than 3 percentage points in any year. Median benefits conditional on receipt are never different by more than 3 percent. The CPS ASEC appears to capture social security income quite well.

Retirement income receipt shows a very different pattern. Starting in 1984, receipt rates are close and actually higher in the CPS ASEC with 29 percent of women in the CPS ASEC reporting retirement income and 23 percent actually having retirement income in the linked sample. Moving to later surveys (and therefore more recent cohorts), the linked sample receipt rates grow rapidly and then reach a plateau, while the CPS ASEC rates remain essentially flat for the entire time period. By 2007, the CPS ASEC shows a receipt rate of 26 percent while the linked sample has a receipt rate over 45 percent. In contrast to receipt rates, survey and administrative measures of (conditional) median amounts continue to track each other reasonably well, except for a large discrepancy in 2003 that diminishes in 2007.

Overall, retirement income underreporting appears to occur mostly at the extensive rather than intensive margin. It is also worth noting that due to its rapid growth, the median amount of retirement income in recent years is now quite close to the median amount of social security income-the difference is that social security receipt remains much more widespread despite retirement income’s growing importance.

The bottom half of Table 3 summarizes the implications for women's total household income. CPS ASEC total income as well as income from five sources (earnings, social security, 
SSI, interest and dividends, and retirement income) are reported. We show income based on these five sources alone because this is directly comparable to the income available in our administrative records. At the $25^{\text {th }}, 50^{\text {th }}$, and $75^{\text {th }}$, percentiles there is a growing dissimilarity between survey and administrative measures of income that parallels the rise in retirement income underreporting. ${ }^{7}$ For example, the median household income is 11 percent higher in the linked data than in the CPS ASEC in $1989(\$ 3,900)$ but is 45 percent higher in $2007(\$ 19,000)$. Note that these are household incomes, so they reflect the effects of underreporting of all household members.

The administrative measures of income seriously change our understanding of the economic progress of women at older ages across cohorts. Across the 1921 to 1925 and 1939 to 1943 cohorts, the CPS ASEC shows an increase in median household income of 21 percent, but the linked data reveal the increase was actually 58 percent. The evenness of economic progress has also been understated. The CPS ASEC shows a monotonic relationship in income growth across the $25^{\text {th }}$, $50^{\text {th }}$, and $75^{\text {th }}$ percentiles of 16 percent, 21 percent, and 25 percent, respectively, but the corresponding numbers in the linked data are 50 percent, 58 percent, and 52 percent.

\section{Work Experience and Underreporting}

If retirement income underreporting has understated economic progress across cohorts, it may also affect our understanding of the relationship between work experience and well-being within a cohort. Table 4 uses administrative records linked to the 2013 CPS ASEC to estimate the relationship between middle to late career work experience and income at older ages for the most recent cohort, those born between 1944 and 1948. We have already established that this

\footnotetext{
${ }^{7}$ We are unable to provideadminis trative estimates of total income for the 1984 sample at this time, but our preliminary analys is suggests the survey and adminis trative estimates are quite close in that year.
} 
cohort is working longer, claiming social security later, and is more likely to receive retirement income than previous cohorts. But there is also significant within-cohort variation.

Using administrative record earnings histories, we calculate whether each woman earned enough in a given year for us to deem that she was employed. We then total the years of employment across the twenty-year period between ages 40 and 59. Next we group women into four experience categories based on the total number of years worked ( 0 to 5,6 to 10,11 to 15 , 16 to 20 years). We show the results for the full sample of women as well as separately by current marital status. Overall, 58 percent of women in the 1944 to 1948 cohort worked at least 16 out of 20 years with a fairly even split across the other categories. The distribution of work experience does not vary much by marital status.

We next examine survey and administrative record measures of retirement income receipt across the experience distribution. The linked CPS ASEC does show that women whose earnings records indicate they spent more years in the labor force are more likely to report receiving retirement income when 65 to 69 years old, with receipt rates rising from 11 percent to 38 percent. But extensive-margin underreporting is present for all four work-experience groups, and the discrepancy is largest in absolute terms for women who work longer, with actual rates ranging from 15 percent to 60 percent. Similar patterns are observed when the sample is restricted to married women, indicating that underreported income is not simply received on account of a deceased spouse.

The next columns of Table 4 illustrate the effects of underreporting for women's own incomes, across the work-experience distribution. Compared with the administrative records, the CPS ASEC actually shows a somewhat higher median own income for the lowest experience 
group and only a slightly lower income for the second experience group. For the higher experience groups, which also have the highest extensive-margin underreporting, the administrative record incomes are a substantial 17 and 22 percent above the survey incomes. Qualitatively similar results are found for both currently and not currently married women.

One implication of these findings is that if future cohorts of women acquire additional years of work experience, household surveys may miss a larger fraction of their own incomes at older ages. However, the relationship between women's work experience and household income is less straightforward, as there is considerable evidence of income underreporting across most work experience groups. The relationship is complicated by the fact that underreporting is also present for other household members who live with women of all experience levels.

Despite the weaker relationship found between women’s work experience and household income underreporting, there are still household income anomalies in the CPS ASEC that the administrative records help to clarify. For example, for married women, survey income does not rise monotonically with women’s work experience. Women who work 6-10 years have a median household income of $\$ 60,700$, while women who work $11-15$ years have a median household income of $\$ 58,600$. Using the administrative records, median incomes are instead ascending for the two groups- $\$ 64,600$ and $\$ 71,100$.

\section{The Retirement Transition}

We have so far explored how underreporting affects women's total incomes at a point in time. We can also exploit the panel nature of the administrative records to track the same women's incomes over time. We focus on a period covering the transition to retirement and examine to what extent women are able to maintain their pre-retirement living standards. 
We draw a sample of women from the 2008 SIPP panel. We use only the most recent SIPP panel because we require data on all types of income for many consecutive years. Like our previous analyses, our sample consists of women who are either the householder or spouse of the householder, who either themselves or their husband (if present) first claimed social security between 2003 and 2007, and who were age 60 to 70 when claiming. We further restrict to those claiming non-disability benefits. Our nine-year panel window runs from three years prior to first claiming benefits until five years after claiming. We also require women to survive to the end of the panel window but place no mortality restrictions on the husband, if present. One limitation is that we only can observe women's living arrangements at the time of the SIPP interview. Therefore, for this exercise we choose to track the total incomes of either the married couple or the not-married women, fixing the marital status at the time of the SIPP interview. However, we do observe mortality of husbands in the administrative records and we equivalence-adjust total incomes in each year to reflect whether our unit of analysis has one or two people. ${ }^{8}$

Figure 5 a plots the mean of the $45^{\text {th }}$ to $55^{\text {th }}$ percentile of equivalence-adjusted overall income in each year for the full sample of women. As shown, the mean of the $45^{\text {th }}$ to $55^{\text {th }}$ percentile is a very close approximation to the median and has the added advantage that it can be decomposed into income-source subcomponents (also plotted). These subcomponents are social security income, earnings, interest and dividends, and retirement income. By construction, social security income is zero in the years prior to claiming and then rises sharply after claiming. Five years after claiming, average equivalence-adjusted social security benefits, for those in the middle of the total income distribution, are a little under $\$ 19,000$. Not surprisingly, income from earnings declines as women and their husbands transition to retirement. Earnings fall from

\footnotetext{
${ }^{8}$ We use the same equivalence scale that is us ed for the Supplemental Poverty Measure. In practice, this simply means dividing our couples' incomes by 1.41. See Short (2015).
} 
$\$ 38,000$ to $\$ 35,000$ in the years before claiming and then accelerate their decline until they are just under $\$ 10,000$ five years after claiming. Interest and dividends are a comparatively small amount of income for most households in all years with a value of just $\$ 2,400$ five years after claiming. Average amounts of retirement income, on the other hand, are substantial. Three years prior to claiming they average close to $\$ 11,000$, and rise after claiming to nearly $\$ 18,000$. Thus, average retirement income and social security amounts are quite comparable for those in the middle of the overall income distribution.

When we examine income from all sources combined, we find that median incomes are surprisingly flat across the full nine-year window, with an approximate value of $\$ 48,600$ both one year before claiming and five years after claiming. In other words, there is little evidence of a drop in median income at retirement and up to five years after retirement. This is in sharp contrast to several previous studies reviewed earlier that suggest substantial drops in income (and consumption) at retirement. Indeed, the premise of the retirement consumption puzzle is that incomes are falling predictably at retirement and that rational, forward-looking households should be able to smooth consumption in response. Although we cannot measure consumption changes directly, our finding of steady incomes surrounding retirement challenges this premise. Crucial to this result is an accurate measure of retirement income from the administrative records.

We also plot event studies separately for college graduate and non-college graduate women and for currently married and not currently married women as shown in Figures 5b through 5e. While the levels of income are quite different across demographic subgroups, the same story holds - total incomes do not fall very much, if at all, in retirement. The biggest drop is for college-educated women where the level of overall income starts higher at around $\$ 77,800$ 
one year before claiming and falls to $\$ 74,500$ five years after claiming. Even this modest drop takes several years to materialize - we never observe a sharp fall in incomes. For women without a college degree, incomes, if anything, rise slightly over the same period from $\$ 40,500$ to $\$ 41,700$. For married women, incomes decline modestly from $\$ 59,200$ to $\$ 57,500$ and for notmarried women, incomes rise slightly from $\$ 28,800$ to $\$ 29,400$.

Beyond total incomes, it is interesting to examine the relative importance of retirement and social security income across demographic groups. Five years after claiming, retirement and social security income are roughly equally important for middle-income women in the full sample. That is, they account for 37 percent and 39 percent of total income, respectively, for women in the middle of the total income distribution. For college graduates, retirement income accounts for 41 percent of the total compared to 26 percent for social security. For non-college graduates, social security is the more dominant income source at 46 percent of the total, although retirement income still makes up an important 34 percent. For married women, the two income sources are equally important at 32 percent, but for not-married women, social security makes up 51 percent of the total, compared with 28 percent for retirement income.

Our findings on women's transition to retirement and the relative importance of retirement income require two caveats. First, our sample consists of those claiming OASI benefits. This removes from the sample those who experience permanent health shocks that would qualify them for SSDI, but who would also likely have declines in their overall incomes. It also ignores the group that has too little earnings to qualify for any social security and is instead receiving SSI. Meyer and Mok (2013) show that consumption does in fact decline after workers become disabled. However, from the perspective of validating the lifecycle model, we would expect consumption to decline exactly for those who do experience negative permanent 
income shocks. Thus, the lifecycle model cannot easily be tested against alternatives in this setting.

Second, although we have provided strong evidence that women's incomes do not fall during the first five years after retirement, this does not necessarily imply that women and their families have saved adequately for retirement. It is still possible that they could "run out of money” in future years should they live longer than expected, incur higher out-of-pocket medical expenses than expected, and have their retirement income exhausted. Relatedly, this analysis examines women (and their husbands) who retired in the mid 2000s, a time where retirees still had considerable retirement income from defined benefit plans. Our results may not extrapolate to future cohorts, who will only have access to defined contribution accounts. Will they save adequately for retirement during working years and then manage to budget their savings during retirement, given that annuitization rates in defined contribution accounts remain low (Hurd and Panis, 2006)?

\section{Conclusion}

We have shown that as women increased employment across cohorts born from the early 1920s to the late 1940s, they also received greater amounts of retirement income at older ages. The CPS ASEC, however, fails to reflect the growing importance of retirement income and thus understates the economic progress of women in retirement. The CPS ASEC has recently been redesigned to improve measures of income received from several sources including retirement accounts. It remains an open question whether the redesign will better capture retirement incomes of future cohorts of women as they continue to work longer.

We have also shown that recently retired (non-disabled) women do not experience noticeable declines in total income at retirement. The finding is in sharp contrast to others in the 
literature on the retirement consumption puzzle. Our results cast doubt on the ability to convincingly test the lifecycle model in this setting. They also imply that total income replacement rates are quite high, at least five years into retirement. Most employee retirement plans are currently completing a transition from defined benefit to defined contribution-based systems. We began with a puzzle that we believe we have solved. We end with the question: will future cohorts of women continue to maintain their pre-retirement standards of living as we have shown past cohorts have done? 


\section{References}

Aguiar, Mark and Erik Hurst. 2005. “Consumption versus Expenditure,” Journal of Political Economy 113(5): 919-48.

Aguiar, Mark and Erik Hurst. 2007. "Life-Cycle Prices and Production,” American Economic Review 97(5): 1533-559.

Autor, David H. and Mark G. Duggan. 2006. "The Growth in the Social Security Disability Rolls: A Fiscal Crisis Unfolding,” Journal of Economic Perspectives 20(3): 71-96.

Banks, James, Richard Blundell and Sarah Tanner. 1998. "Is There a Retirement-Savings Puzzle?” American Economic Review 88(4): 769-88.

Bee, C. Adam. 2013. "An Evaluation of Retirement Income in the CPS ASEC Using Form 1099-R Microdata.”

http://www.census.gov/content/dam/Census/library/w orking-papers/2013/demo/Bee-PAApaper.pdf

Bee, C. Adam and Joshua Mitchell. (In progress). "Do Older Americans Have More Income than We Think?"

Bernheim, B. Douglas, Jonathan Skinner and Steven Weinberg. 2001. "What Accounts for the Variation in Retirement Wealth among U.S. Households?” American Economic Review 91(4): 832-57.

Brady, Peter J., Steven Bass, Jessica Holland, and Kevin Pierce. (In progress). "Using Panel Tax Data to Examine the Transition to Retirement.”

Cutler, David M. and Lawrence F. Katz. 1991. "Macroeconomic Performance and the Disadvantaged,” Brookings Papers on Economic Activity 1991(2): 1-74.

Czajka, John L. and Gabrielle Denmead. 2012. "Getting More from Survey Income Measures: Empirically Based Recommendations for Improving Accuracy and Efficiency.” Working paper, presented at 2012 Federal Committee on Statistical Methodology Research Conference. https:/fcsm.sites.usa.gov/files/2014/05/Czajka_2012FCSM_III-D.pdf

DeNavas-Walt, Carmen and Bernadette D. Proctor. "Income and Poverty in the United States: 2014,” U.S. Census Bureau, Current Population Reports P60-252. 2015.

Dushi, Irena and Howard M. Iams. 2010. "The Impact of Response Error on Participation Rates and Contributions to Defined Contribution Pension Plans,” Social Security Bulletin 70(1): 45-60. 
Dushi, Irena and Marjorie Honig. 2015. "How Much Do Respondents in the Health and Retirement Study Know About Their Contributions to Tax-Deferred Contribution Plans? A Cross-Cohort Comparison,” Journal of Pension Economics and Finance 14(3): 203-39.

Goldin, Claudia. 2006. “The Quiet Revolution that Transformed Women’s Employment, Education, and Family.” American Economic Review 96(2), 1-21.

Goldin, Claudia and Joshua Mitchell. Forthcoming. “The New Lifecycle of Women's Employment: Disappearing Humps, Sagging Middles, Expanding Tops,” Journal of Economic Perspectives.

Goldin, Claudia, Lawrence F. Katz and Ilyana Kuziemko, 2006. "The Homecoming of American College Women: The Reversal of the College Gender Gap," Journal of Economic Perspectives 20(4), 133-56.

Goldin, Claudia and Lawrence F. Katz, 2016. "Women Working Longer: Facts and Some Explanations.” (this volume).

Gustman, Alan L., Thomas L. Steinmeier and Nahid Tabatabai. 2010. Pensions in the Health and Retirement Study. Harvard University Press.

Hurd, Michael and Constantijn Panis. 2006. "The Choice to Cash Out Pension Rights at Job Change or Retirement." Journal of Public Economics 90(12): 2213-227.

Hurd, Michael and Susann Rohwedder. 2006. "Economic Well-Being at Older Ages: Incomeand Consumption-Based Poverty Measures in the HRS.” Working paper, November. https:/www.rand.org/content/dam/rand/pubs/working_papers/2007/RAND_WR410.pdf

Hurst, Erik. 2008. "Understanding Consumption in Retirement: Recent Developments," in J. Ameriks and O. Mitchell, eds., Recalibrating Retirement Spending and Saving. Oxford University Press.

Lusardi, Annamaria and Olivia S. Mitchell. 2014. "The Economic Importance of Financial Literacy: Theory and Evidence,” Journal of Economic Literature 52(1): 5-44.

Lusardi, Annamaria and Olivia S. Mitchell. 2016. “Older Women’s Labor Market Attachment, Retirement Planning, and Household Debt,” in C. Goldin and L. Katz, eds., Women Working Longer, this volume.

Meyer, Bruce and James X. Sullivan. 2010. "Consumption and Income of the Poor Elderly Since 1960." Working paper, September. Earlier version available as "Consumption and Income Poverty for those 65 and Over." http://www3.nd.edu/ jsulliv4/Elderly_Poverty3.4.pdf

Meyer, Bruce and James X. Sullivan. 2012. "Winning the War: Poverty from the Great Society to the Great Recession,” Brookings Papers on Economic Activity 2012(2): 133-200. 
Meyer, Bruce and Wallace K.C. Mok. 2013. "Disability, Earnings, Income, and Consumption.” NBER Working Paper 18869.

Mitchell, Joshua and Trudi Renwick. 2015. "A Comparison of Official Poverty Estimates in the Redesigned Current Population Survey Annual Social and Economic Supplement,” SEHSD Working Paper \#2014-35, January.

https:/www.census.gov/content/dam/Census/library/working-papers/2014/demo/SEHSDWP2014-35.pdf

Mitchell, Olivia. 1988. “Worker Knowledge of Pension Provisions,” Journal of Labor Economics 6(1): 21-39.

Munnell, Alicia and Anqi Chen. 2014. “Do Census Data Understate Retirement Income?” Center for Retirement Research Working Paper \#14-19, December.

http://crr.bc.edu/wp-content/uploads/2014/12/IB_14-19-508.pdf

Semega, Jessica L. and Edward Welniak, Jr. 2015. "The Effects of Changes to the Current Population Survey Annual Social and Economic Supplement on Estimates of Income.” Paper presented at the 2015 Allied Social Science Association Meetings. https:/www.census.gov/content/dam/Census/library/working-papers/2015/DEMO/ASSAIncome-CPSASEC-Red.pdf

Short, Kathleen. 2015. “The Supplemental Poverty Measure: 2014,” Current Population Survey Reports \#P60-254.

Wagner, Deborah and Mary Layne. 2014. “The Person Identification Validation System (PVS): Applying the Center for Administrative Records Research and Applications’ (CARRA) Record Linkage Software.” CARRA Working Paper Series \#2014-01. https://www.census.gov/srd/carra/CARRA_PVS_Record_Linkage.pdf 
Figure 1: Trends in Retirement Income Receipt for Women who Receive Social Security

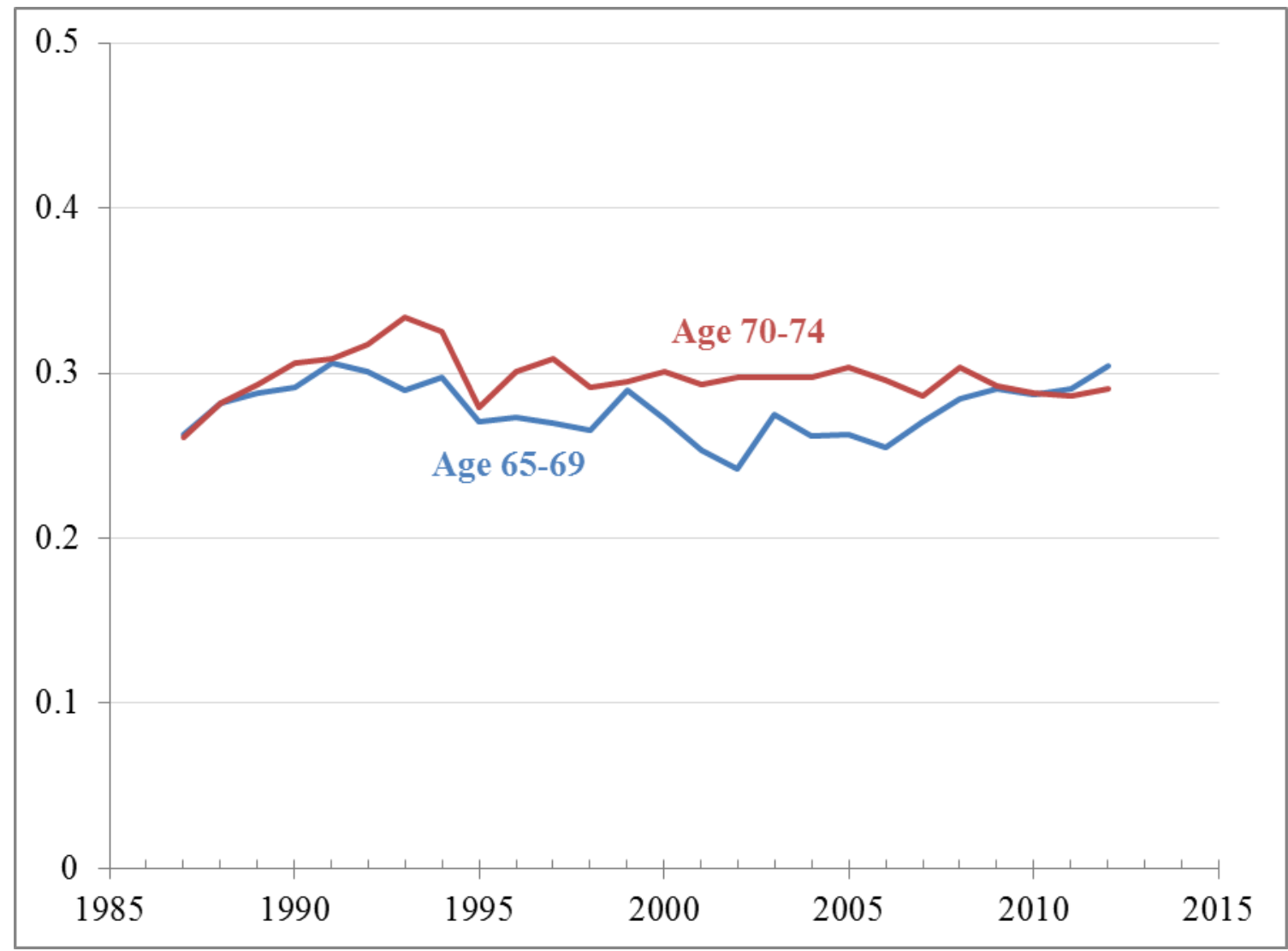

Source: 1988 to 2013 CPS ASEC surveys.

Notes: Sample is all women ages 65 to 69 and 70 to 74 who received social security income in the reference year. "Retirement Income Receipt" is the fraction of women with positive retirement, survivor, or disability income in the reference year, excluding social security income and VA benefits. CPS ASEC survey weights are used in analysis. 
Figure 2: Employment Rates for Women by Age and Cohort

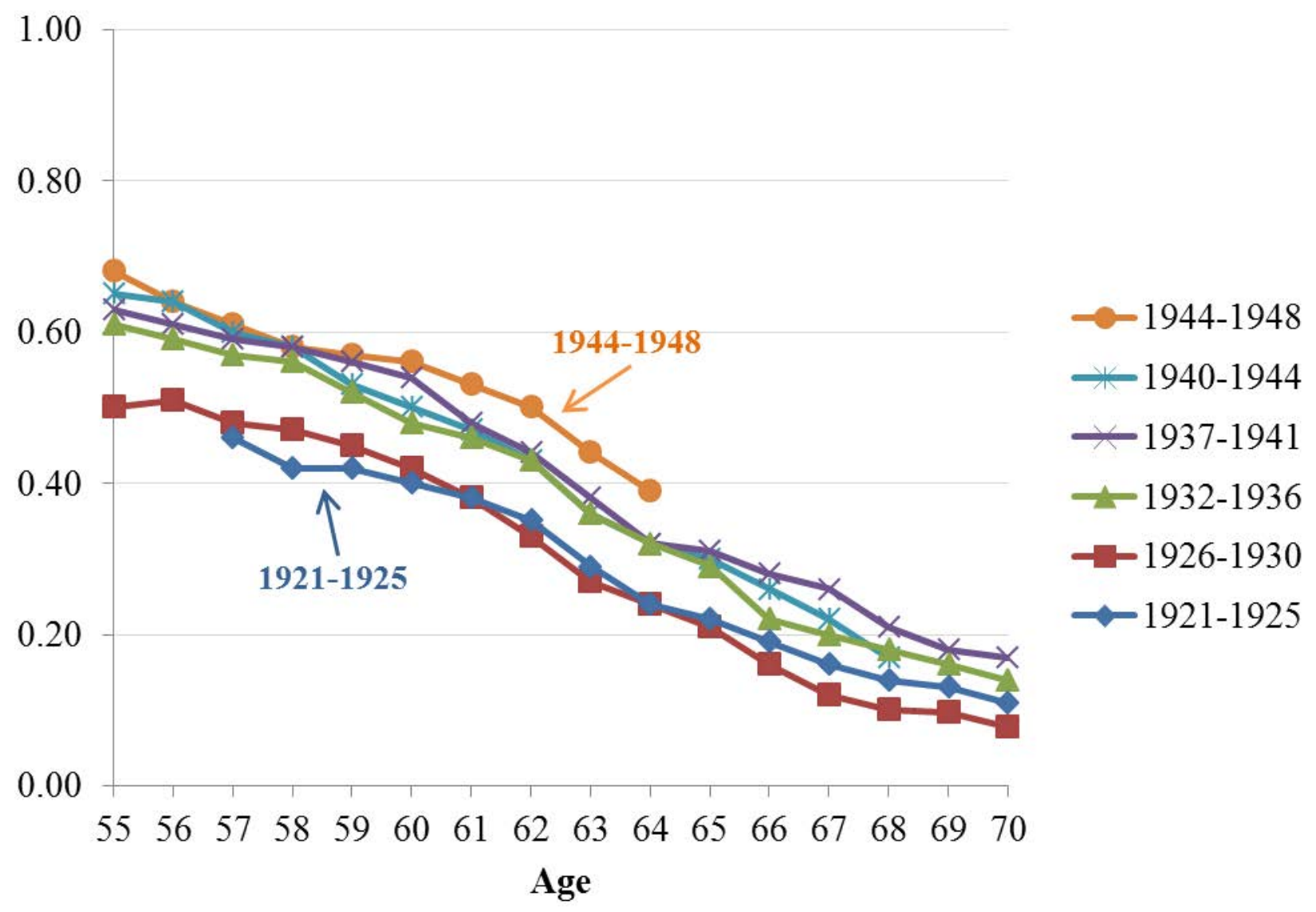

Source:SIPP Gold Standard File linked to Social Security Administration and IRS administrative records.

Notes: Sample is all women who are either the SIPP householder or spouse of the householder, are ages 60 to 64 at time of SIPP interview, and survive until age 70 . Women are considered as working in a given year if their total earnings from wages and self-employment in the administrative records are at least equal to the prevailing hourly federal minimum wage in that year times 10 hours per week times 52 weeks per year.

Sample is restricted to those with a Personal Identification Key (PIK) that allows linking to the administrative records. SIPP sample weights are adjusted to account for selection into having a PIK. For each SIPP panel we estimate a logit model for the presence of a PIK as a function of SIPP demographic characteristics and predict the estimated propensity score. We then take the SIPP sample weight and multiply it by the inverse of the estimated propensity score. Resulting weights are used in analysis. 
Figure 3: Social Security Receipt Rates for Women by Age and Cohort

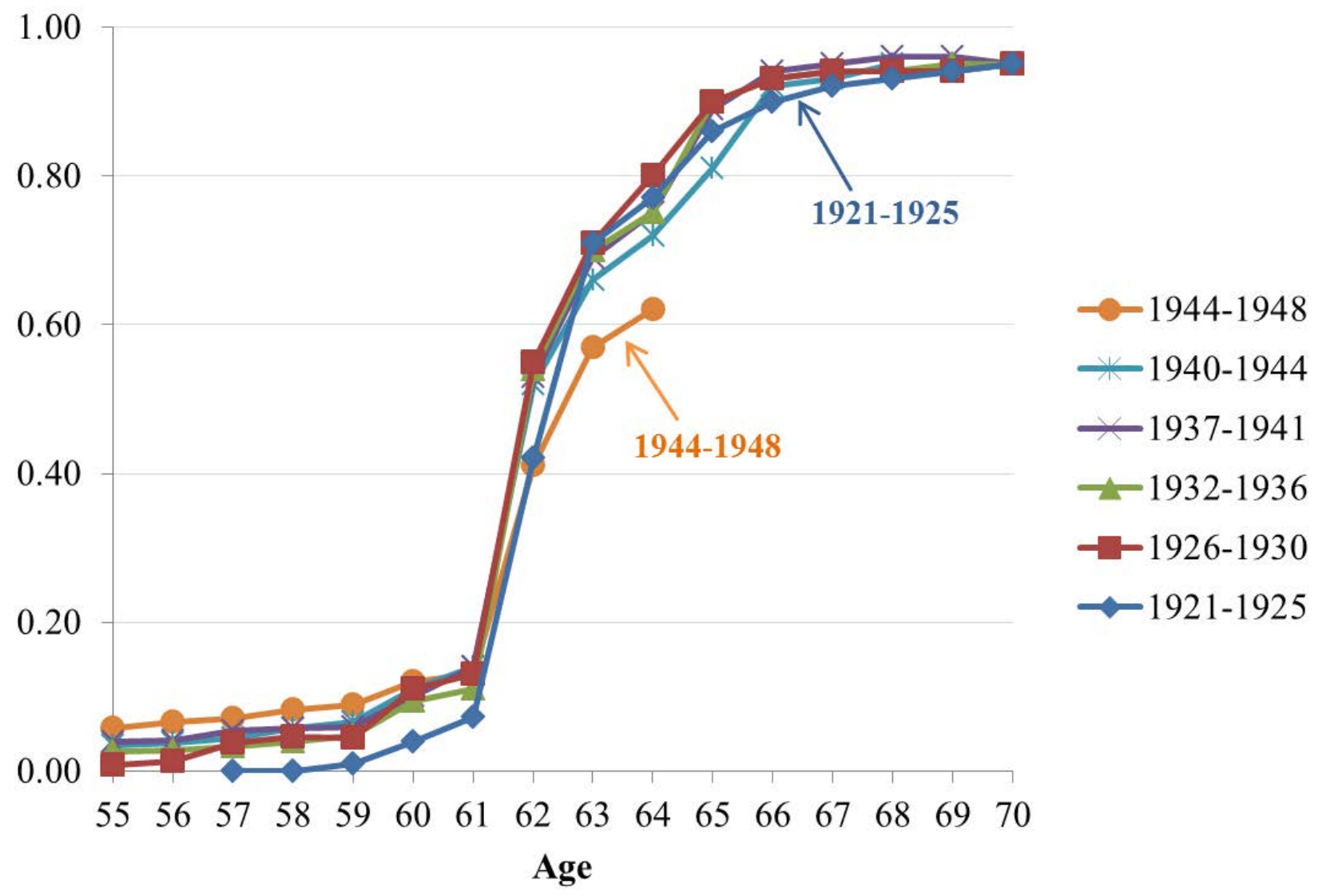

Source:SIPP Gold Standard File linked to Social Security Administration and IRS administrative records.

Notes: Sample is all women who are either the SIPP householder or spouse of the householder, ages 60 to 64 at time of SIPP interview, and survive until age 70 . Social security receipt in a given year is defined as having positive annual OASDI benefits in the administrative records for that year.

Sample is restricted to those with a Personal Identification Key (PIK) that allows linking to the administrative records. SIPP sample weights are adjusted to account for selection into having a PIK. For each SIPP panel we estimate a logit model for the presence of a PIK as a function of SIPP demographic characteristics and predict the estimated propensity score. We then take the SIPP sample weight and multiply it by the inverse of the estimated propensity score. Resulting weights are used in analysis. 
Figure 4: Retirement Income Receipt Rates for Women by Age and Cohort

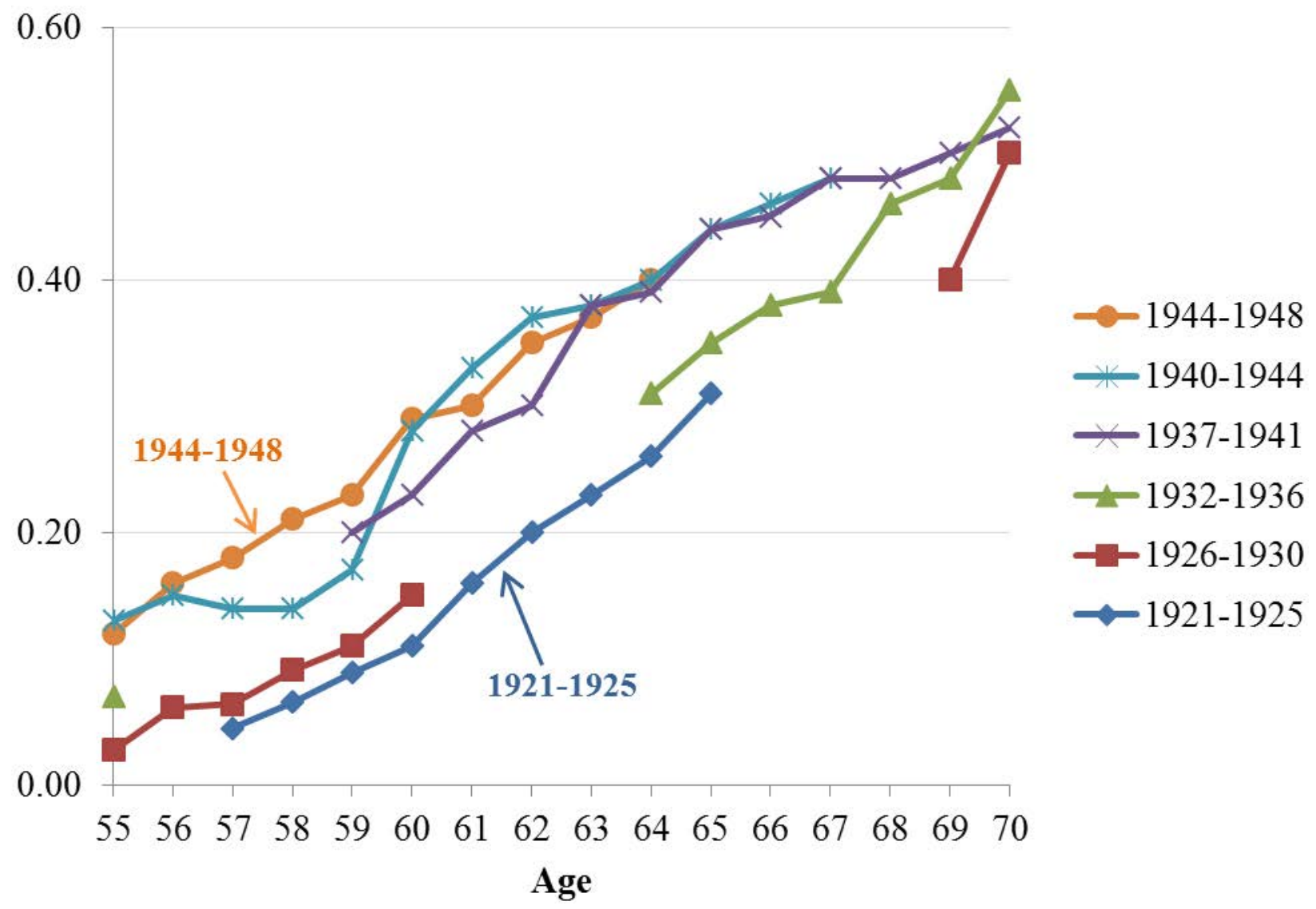

Source:SIPP Gold Standard File linked to Social Security Administration and IRS administrative records.

Notes: Sample is all women who are either the SIPP householder or spouse of the householder, ages 60 to 64 at time of SIPP interview, and survive until age 70. Retirement income receipt in a given year is defined as having positive annual retirement income in the $\mathrm{W}$-2P records for years 1978 to 1990 and in the 1099-R records for years 1995 to 2012. Retirement income includes pension/annuity income as well as periodic withdrawals from defined contribution accounts. Gaps in series refer to years 1991 to 1994 where administrative records are not available.

Sample is restricted to those with a Personal Identification Key (PIK) that allows linking to the administrative records. SIPP sample weights are adjusted to account for selection into having a PIK. For each SIPP panel we estimate a logit model for the presence of a PIK as a function of SIPP demographic characteristics and predict the estimated propensity score. We then take the SIPP sample weight and multiply it by the inverse of the estimated propensity score. Resulting weights are used in analysis. 
Figure 5: Mean of the $4^{\text {th }}-55^{\text {th }}$ Percentile of Total Income and Its Subcomponents A. All Women

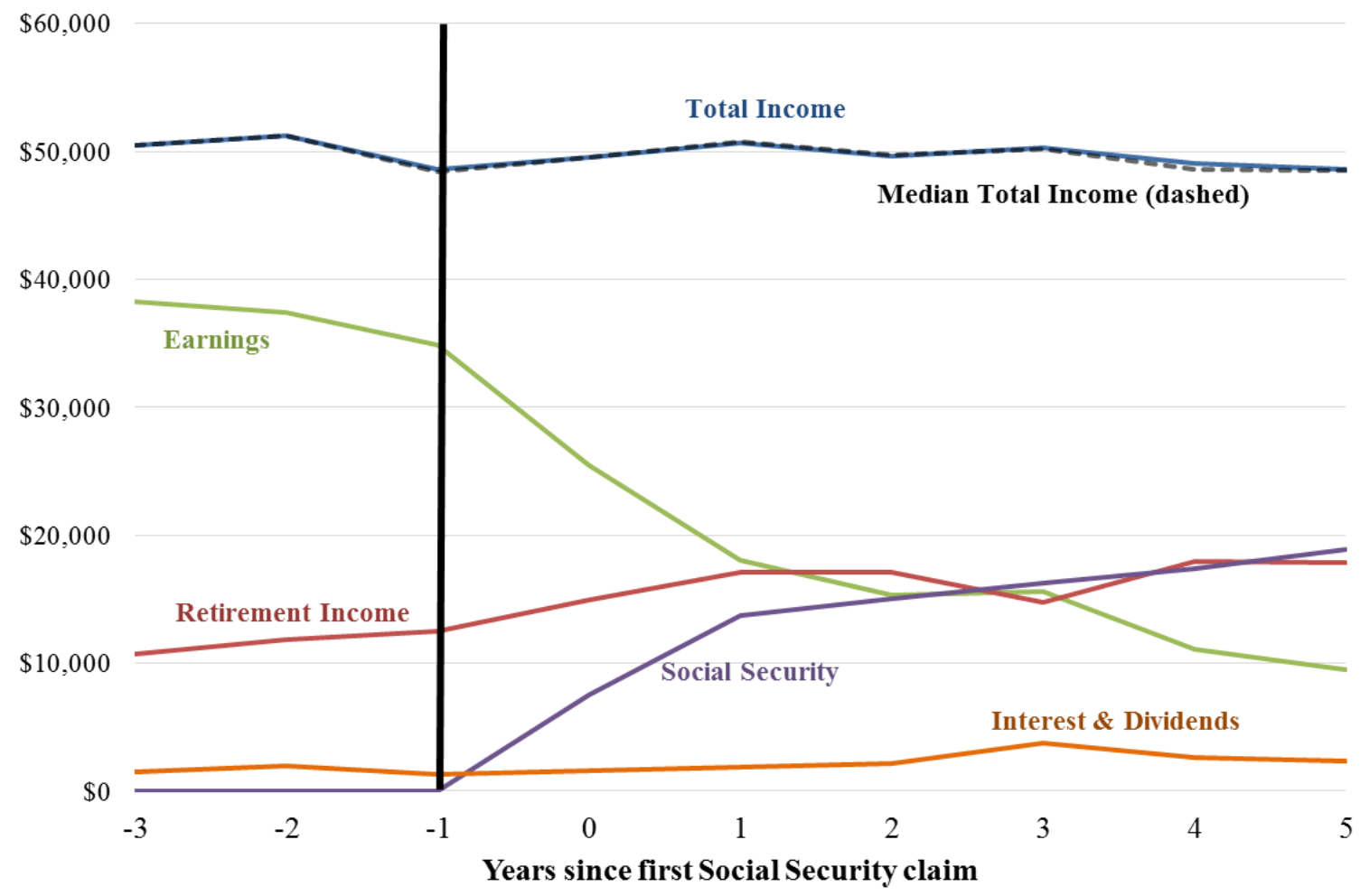

Source:SIPP Gold Standard File linked to Social Security Administration and IRS administrative records.

Notes: Sample is all women from 2008 SIPP panel who are householder or spouse of householder, either first claimed or their spouse (if present) first claimed social security benefits between 2003 and 2007, did not claim disability benefits, and survived for full nine-year window. Total income is the sum for the women and her spouse (if present) of administrative record amounts of earnings, social security, interest and dividends, and retirement income. Income amounts are equivalence-adjusted by dividing by 1.41 for married couples. See Short (2015) for more details. Marital status is determined as of SIPP interview date but is adjusted if administrative records indicate death of husband. Incomes are inflation-adjusted using the CPIU-RS deflator and are expressed in 2012 dollars. Mean of the $45^{\text {th }}$ to $55^{\text {th }}$ percentiles in each year is calculated as well as the median for total income. Mean amounts of each subcomponent of total income are also displayed for those with total incomes in the $45^{\text {th }}$ to $55^{\text {th }}$ percentile range.

Sample is restricted to those with a Personal Identification Key (PIK) that allows linking to the administrative records. SIPP sample weights are adjusted to account for selection into having a PIK. For each SIPP panel we estimate a logit model for the presence of a PIK as a function of SIPP demographic characteristics and predict the estimated propensity score. We then take the SIPP sample weight and multiply it by the inverse of the estimated propensity score. Resulting weights are used in analysis. 
B. College Graduate Women

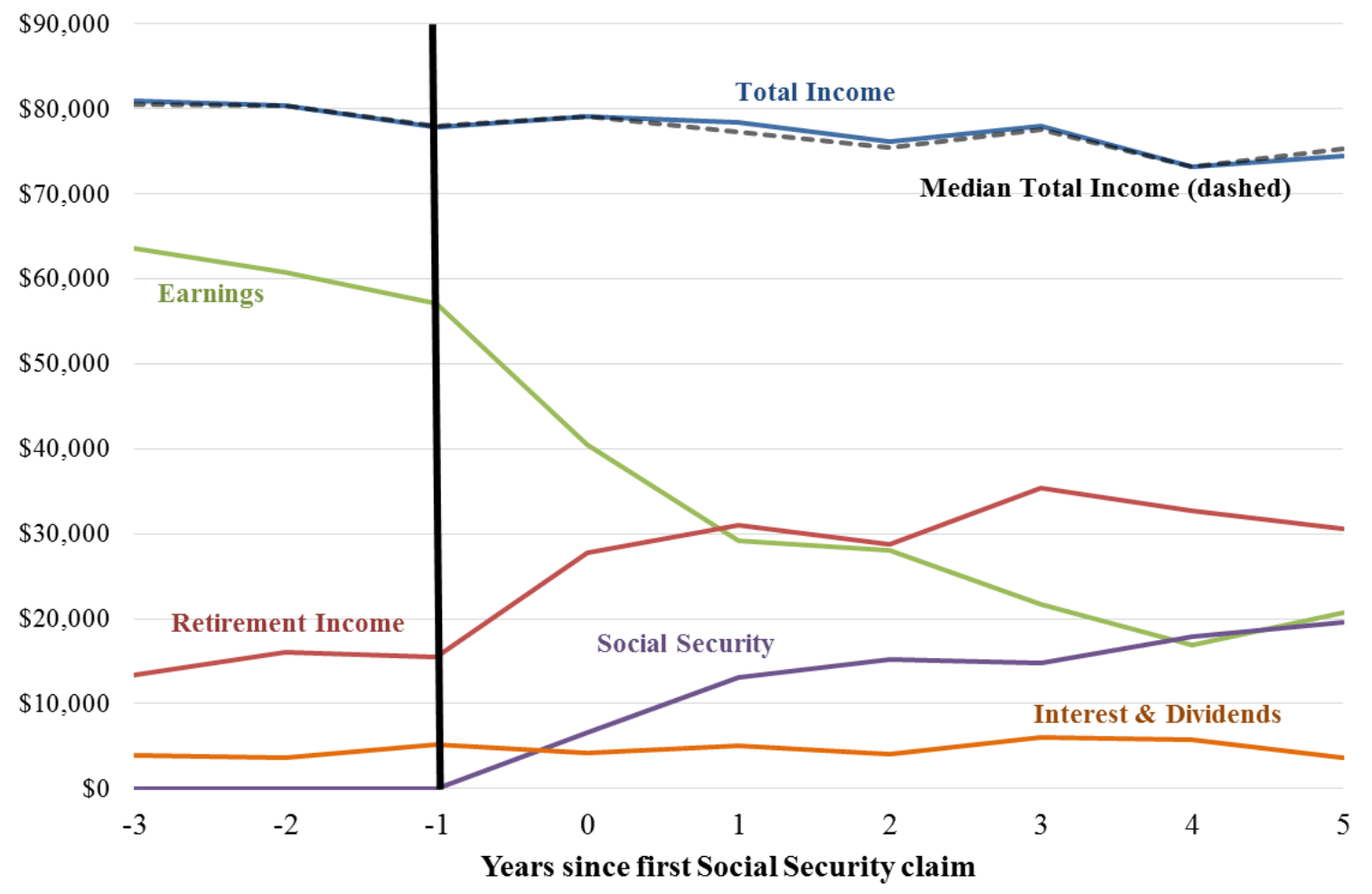

Source:SIPP Gold Standard File linked to Social Security Administration and IRS administrative records.

Notes: Sample is college graduate women from the 2008 SIPP panel who are householder or spouse of householder, either first claimed or their spouse (if present) first claimed social security benefits between 2003 and 2007, did not claim disability benefits, and survived for full nine-year window. Total income is the sum for the women and her spouse (if present) of administrative record amounts of earnings, social security, interest and dividends, and retirement income. Income amounts are equivalence-adjusted by dividing by 1.41 for married couple. See Short (2015) for more details. Marital status is determined as of SIPP interview date but is adjusted if administrative records indicate death of husband. Incomes are inflation-adjusted using the CPI-U-RS deflator and are expressed in 2012 dollars. Mean of the $45^{\text {th }}$ to $55^{\text {th }}$ percentiles in each year is calculated as well as the median for total income. Mean amounts of each subcomponent of total income are also displayed for those with total incomes in the $45^{\text {th }}$ to $55^{\text {th }}$ percentile range.

Sample is restricted to those with a Personal Identification Key (PIK) that allows linking to the administrative records. SIPP sample weights are adjusted to account for selection into having a PIK. For each SIPP panel we estimate a logit model for the presence of a PIK as a function of SIPP demographic characteristics and predict the estimated propensity score. We then take the SIPP sample weight and multiply it by the inverse of the estimated propensity score. Resulting weights are used in analysis. 
C. Non-College Graduate Women

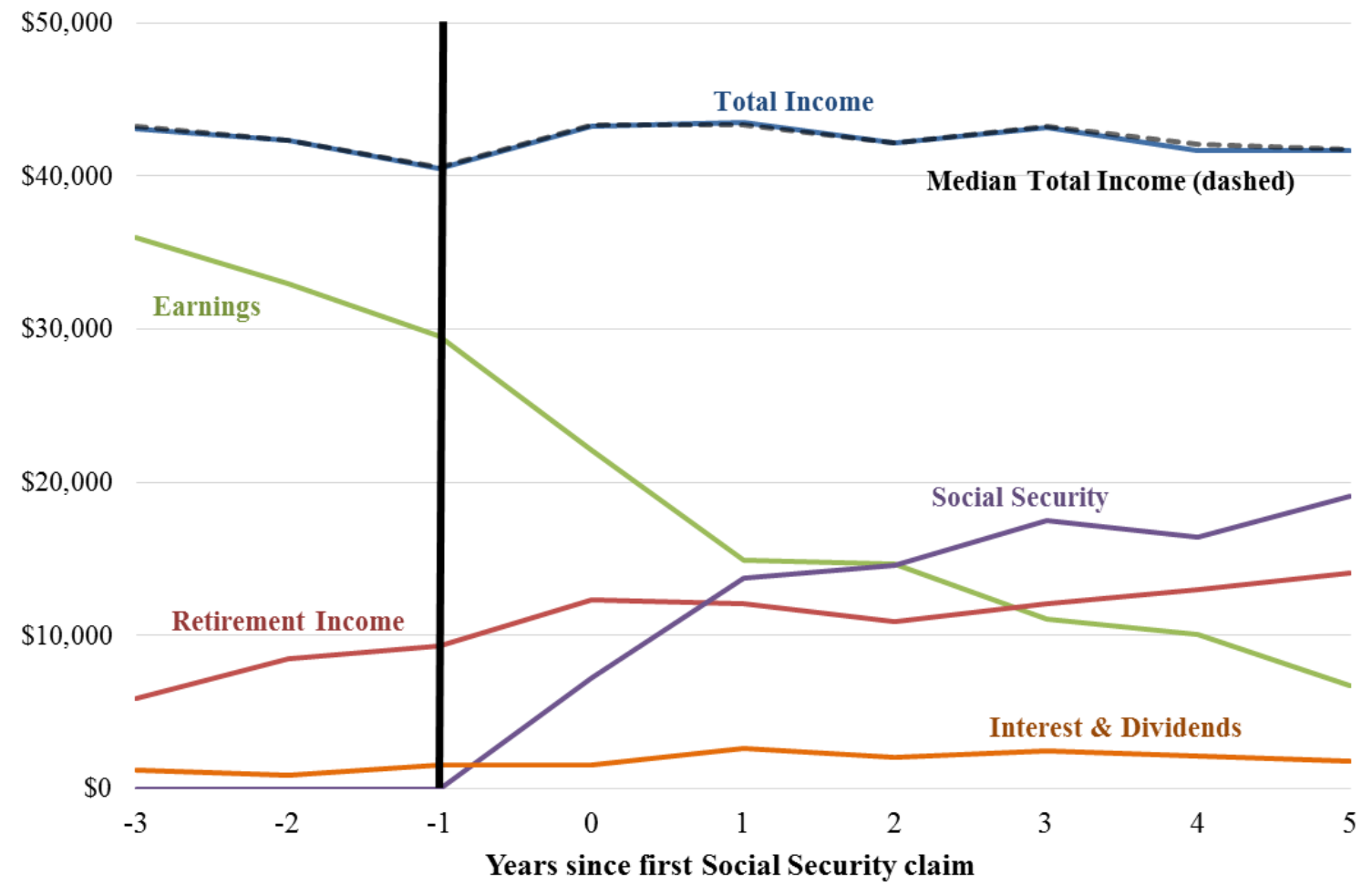

Source:SIPP Gold Standard File linked to Social Security Administration and IRS administrative records.

Notes: Sample is non-college graduate women from the 2008 SIPP panel who are householder or spouse of householder, either first claimed or their spouse (if present) first claimed social security benefits between 2003 and 2007, did not claim disability benefits, and survived for full nine-year window. Total income is the sum for the women and her spouse (if present) of administrative record amounts of earnings, social security, interest and dividends, and retirement income. Income amounts are equivalence-adjusted by dividing by 1.41 for married couple. See Short (2015) for more details. Marital status is determined as of SIPP interview date but is adjusted if administrative records indicate death of husband. Incomes are inflation-adjusted using the CPI-U-RS deflator and are expressed in 2012 dollars. Mean of the $45^{\text {th }}$ to $55^{\text {th }}$ percentiles in each year is calculated as well as the median for total income. Mean amounts of each subcomponent of total income are also displayed for those with total incomes in the $45^{\text {th }}$ to $55^{\text {th }}$ percentile range.

Sample is restricted to those with a Personal Identification Key (PIK) that allows linking to the administrative records. SIPP sample weights are adjusted to account for selection into having a PIK. For each SIPP panel we estimate a logit model for the presence of a PIK as a function of SIPP demographic characteristics and predict the estimated propensity score. We then take the SIPP sample weight and multiply it by the inverse of the estimated propensity score. Resulting weights are used in analysis. 
D. Married Women

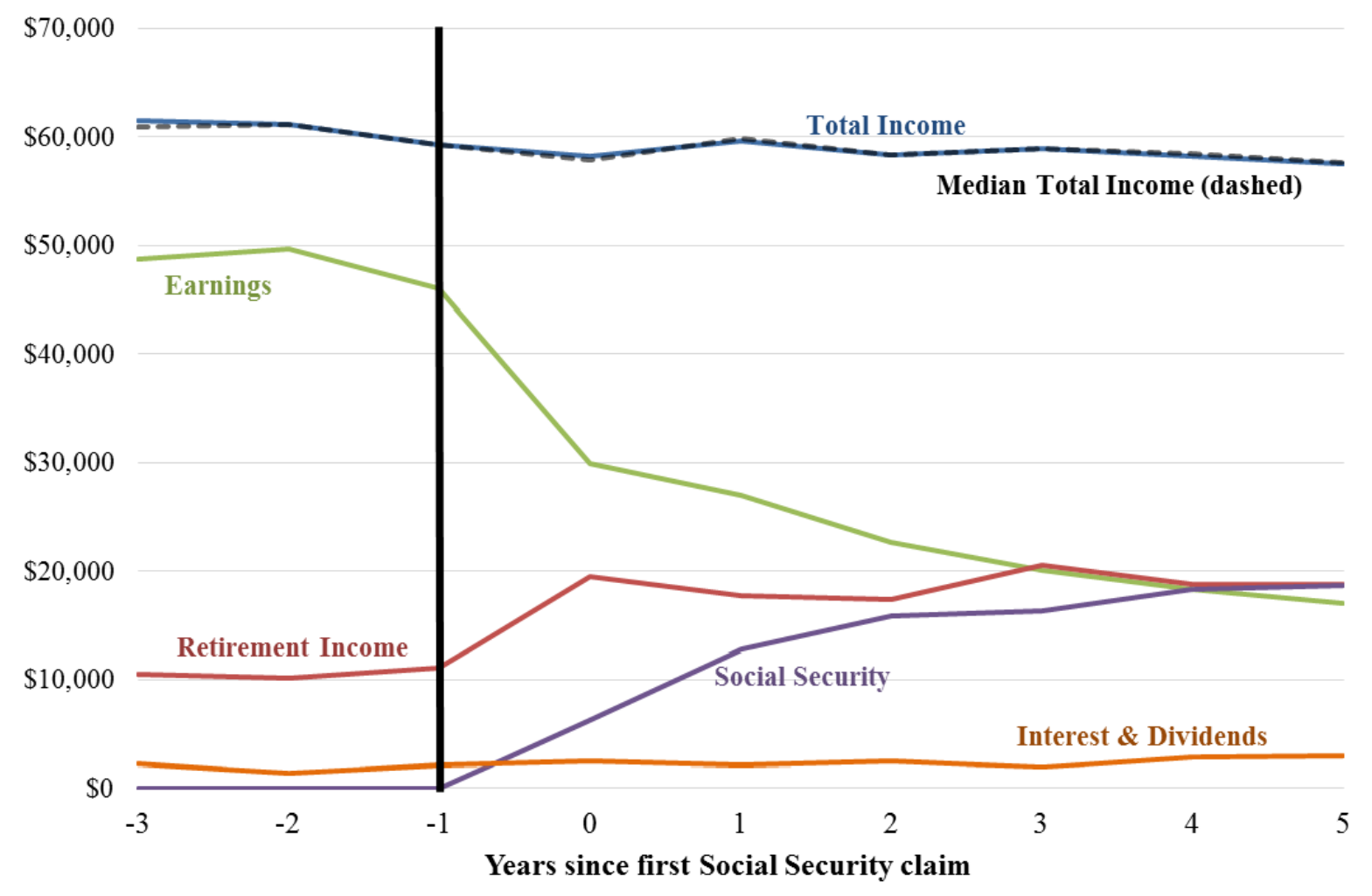

Source:SIPP Gold Standard File linked to Social Security Administration and IRS administrative records.

Notes: Sample is married women from the 2008 SIPP panel who are householder or spouse of householder, either first claimed or their spouse (if present) first claimed social security benefits between 2003 and 2007, did not claim disability benefits, and survived for full nine-year window. Total income is the sum for the women and her spouse (if present) of administrative record amounts of earnings, social security, interest and dividends, and retirement income. Income amounts are equivalence-adjusted by dividing by 1.41 for married couple. See Short (2015) for more details. Marital status is determined as of SIPP interview date but is adjusted if administrative records indicate death of husband. Incomes are inflation-adjusted using the CPIU-RS deflator and are expressed in 2012 dollars. Mean of the $45^{\text {th }}$ to $55^{\text {th }}$ percentiles in each year is calculated as well as the median for total income. Mean amounts of each subcomponent of total income are also displayed for those with total incomes in the $45^{\text {th }}$ to $55^{\text {th }}$ percentile range.

Sample is restricted to those with a Personal Identification Key (PIK) that allows linking to the administrative records. SIPP sample weights are adjusted to account for selection into having a PIK. For each SIPP panel we estimate a logit model for the presence of a PIK as a function of SIPP demographic characteristics and predict the estimated propensity score. We then take the SIPP sample weight and multiply it by the inverse of the estimated propensity score. Resulting weights are used in analysis. 


\section{E. Not-Married Women}

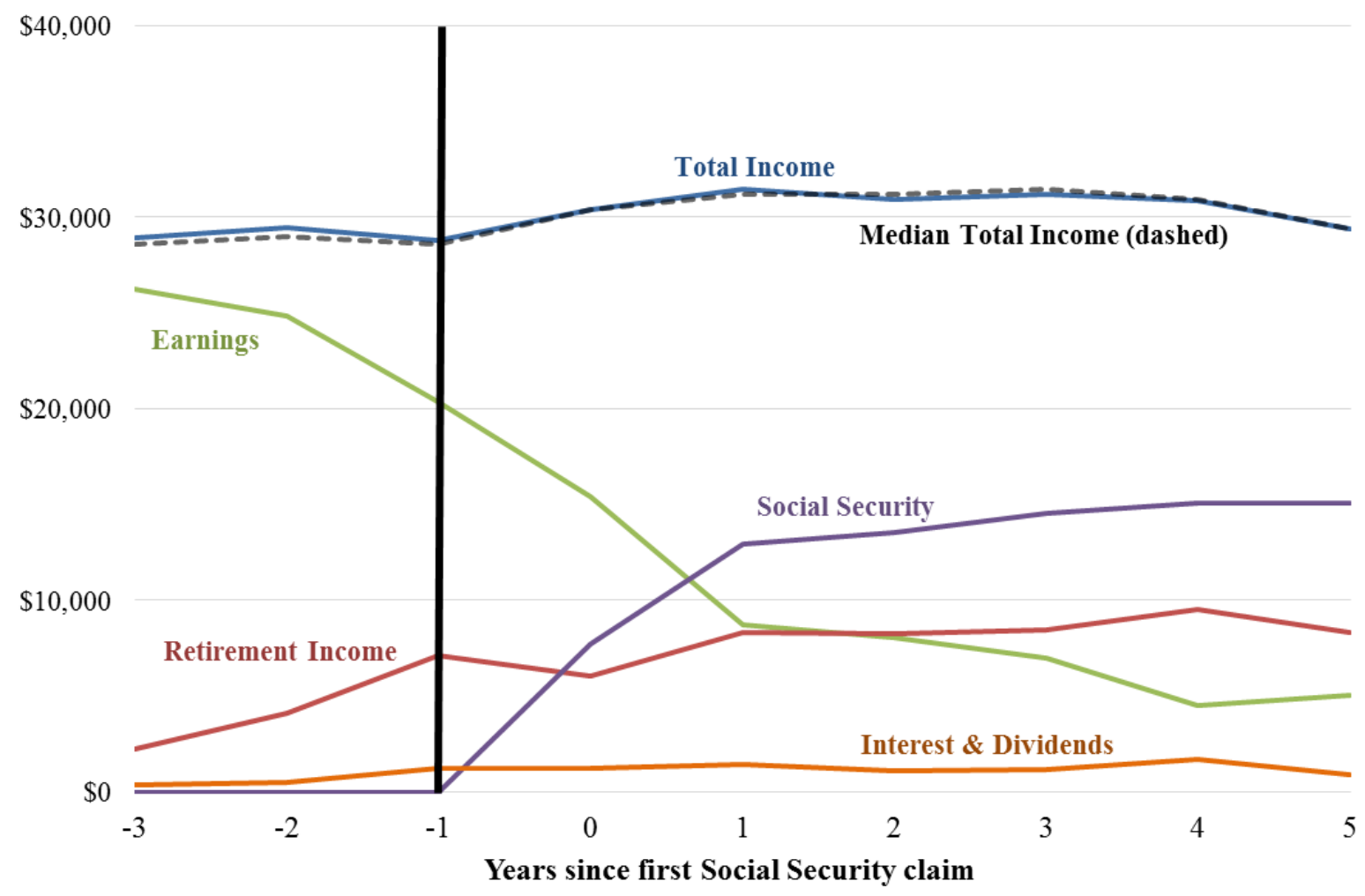

Source: SIPP Gold Standard File linked to Social Security Administration and IRS administrative records.

Notes: Sample is women from the 2008 SIPP panel who are not currently married and are the householder, either first claimed or their spouse (if present) first claimed social security benefits between 2003 and 2007, did not claim disability benefits, and survived for full nine-year window. Total income is the sum for the women and her spouse (if present) of administrative record amounts of earnings, social security, interest and dividends, and retirement income. Income amounts are equivalence-adjusted by dividing by 1.41 for married couple. See Short (2015) for more details. Marital status is determined as of SIPP interview date but is adjusted if administrative records indicate death of husband. Incomes are inflation-adjusted using the CPIU-RS deflator and are expressed in 2012 dollars. Mean of the $45^{\text {th }}$ to $55^{\text {th }}$ percentiles in each year is calculated as well as the median for total income. Mean amounts of each subcomponent of total income are also displayed for those with total incomes in the $45^{\text {th }}$ to $55^{\text {th }}$ percentile range.

Sample is restricted to those with a Personal Identification Key (PIK) that allows linking to the administrative records. SIPP sample weights are adjusted to account for selection into having a PIK. For each SIPP panel we estimate a logit model for the presence of a PIK as a function of SIPP demographic characteristics and predict the estimated propensity score. We then take the SIPP sample weight and multiply it by the inverse of the estimated propensity score. Resulting weights are used in analysis. 
Table 1: Summary Statistics

\begin{tabular}{ccccc}
\hline \hline $\begin{array}{c}\text { SIPP } \\
\text { Panel }\end{array}$ & $\begin{array}{c}\text { Birth Cohort } \\
\text { Group }\end{array}$ & $\begin{array}{c}\text { Approximate } \\
\mathrm{N}\end{array}$ & $\begin{array}{c}\text { College } \\
\text { Graduate }\end{array}$ & Married \\
\hline 1984 & $1921-1925$ & 900 & 0.12 & 0.72 \\
1990 & $1926-1930$ & 900 & 0.11 & 0.70 \\
1996 & $1932-1936$ & 1200 & 0.15 & 0.74 \\
2001 & $1937-1941$ & 700 & 0.20 & 0.68 \\
2004 & $1940-1944$ & 1800 & 0.24 & 0.68 \\
2008 & $1944-1948$ & 2400 & 0.27 & 0.68 \\
\hline \hline
\end{tabular}

Sources: SIPP Gold Standard File linked to Social Security Administration and IRS administrative records.

Notes: Sample is all women who are either the SIPP householder or spouse of the householder, ages 60 to 64 at time of SIPP interview, and survive until age 70 . College completion and marital status are measured at time of SIPP interview. Sample is restricted to those with a Personal Identific ation Key (PIK) that allows linking to the administrative records. SIPP sample weights are adjusted to account for selection into having a PIK. For each SIPP panel we estimate a logit model for the presence of a PIK as a function of SIPP demographic characteristics and predict the estimated propensity score. We then take the SIPP sample weight and multiply it by the inverse of the estimated propensity score. Resulting weights are used in analysis. 
Table 2: Employment and Income Receipt Regressions

\begin{tabular}{|c|c|c|c|c|c|c|}
\hline \multirow{2}{*}{$\begin{array}{l}\text { Independent } \\
\text { variable }\end{array}$} & \multicolumn{2}{|c|}{$\begin{array}{c}\text { Employed } \\
\text { (Ages 57-64) }\end{array}$} & \multicolumn{2}{|c|}{$\begin{array}{c}\text { Receives } \\
\text { Social Security Early } \\
\text { (Ages 62-64) } \\
\end{array}$} & \multicolumn{2}{|c|}{$\begin{array}{c}\text { Receives } \\
\text { Retirement Income } \\
\text { (Ages 59-64) } \\
\end{array}$} \\
\hline & $(1)$ & $(2)$ & (3) & (4) & $(5)$ & (6) \\
\hline \multicolumn{7}{|c|}{ Cohort (1921-1925 omitted) } \\
\hline 1926-1930 & $\begin{array}{r}0.009 \\
(0.021)\end{array}$ & $\begin{array}{r}0.009 \\
(0.021)\end{array}$ & $\begin{array}{l}0.052^{* *} \\
(0.022)\end{array}$ & $\begin{array}{c}0.049^{* *} \\
(0.021)\end{array}$ & & \\
\hline 1932-1936 & $\begin{array}{l}0.093^{* * *} \\
(0.019)\end{array}$ & $\begin{array}{l}0.072^{* * *} \\
(0.019)\end{array}$ & $\begin{array}{r}0.031 \\
(0.019)\end{array}$ & $\begin{array}{l}0.049^{* * *} \\
(0.019)\end{array}$ & & \\
\hline 1937-1941 & $\begin{array}{l}0.117^{* * *} \\
(0.022)\end{array}$ & $\begin{array}{l}0.072^{* * *} \\
(0.022)\end{array}$ & $\begin{array}{r}0.023 \\
(0.022)\end{array}$ & $\begin{array}{l}0.060^{* * *} \\
(0.022)\end{array}$ & $\begin{array}{l}0.120^{* * *} \\
(0.018)\end{array}$ & $\begin{array}{l}0.092^{* * *} \\
(0.018)\end{array}$ \\
\hline $1940-1944$ & $\begin{array}{l}0.104^{* * *} \\
(0.020)\end{array}$ & $\begin{array}{l}0.042^{* *} \\
(0.021)\end{array}$ & $\begin{array}{r}0.000 \\
(0.021)\end{array}$ & $\begin{array}{c}0.049^{* *} \\
(0.021)\end{array}$ & $\begin{array}{l}0.146^{* * *} \\
(0.019)\end{array}$ & $\begin{array}{l}0.105^{* * *} \\
(0.018)\end{array}$ \\
\hline $1944-1948$ & $\begin{array}{l}0.150^{* * *} \\
(0.020)\end{array}$ & $\begin{array}{l}0.079^{* * *} \\
(0.020)\end{array}$ & $\begin{array}{l}-0.101^{* * *} \\
(0.020)\end{array}$ & $\begin{array}{c}-0.0399^{*} \\
(0.021)\end{array}$ & $\begin{array}{l}0.148^{* * *} \\
(0.017)\end{array}$ & $\begin{array}{l}0.105^{* * *} \\
(0.017)\end{array}$ \\
\hline \multicolumn{7}{|c|}{ Marital status (Never married omitted) } \\
\hline Married & & $\begin{array}{l}-0.161^{* * *} \\
(0.034)\end{array}$ & & $\begin{array}{l}0.1600^{* * *} \\
(0.038)\end{array}$ & & $\begin{array}{l}-0.101^{* * *} \\
(0.036)\end{array}$ \\
\hline Widowed & & $\begin{array}{l}-0.129^{* * *} \\
(0.037)\end{array}$ & & $\begin{array}{l}0.262^{* * *} \\
(0.041)\end{array}$ & & $\begin{array}{c}0.083^{* *} \\
(0.042)\end{array}$ \\
\hline Divorced & & $\begin{array}{r}0.006 \\
(0.038)\end{array}$ & & $\begin{array}{c}0.079 \\
(0.042)\end{array}$ & & $\begin{array}{r}-0.038 \\
(0.040)\end{array}$ \\
\hline Separated & & $\begin{array}{l}-0.1566^{* *} \\
(0.064)\end{array}$ & & $\begin{array}{r}0.082 \\
(0.081)\end{array}$ & & $\begin{array}{r}-0.110 \\
(0.109)\end{array}$ \\
\hline
\end{tabular}


Educational attainment (Less than HS grad omitted)

\begin{tabular}{|c|c|c|c|c|c|c|}
\hline \multicolumn{2}{|l|}{ HS grad } & $\begin{array}{l}0.140 \text { *** } \\
(0.016)\end{array}$ & & $\begin{array}{r}-0.017 \\
(0.017)\end{array}$ & & $\begin{array}{c}0.088^{* * *} \\
(0.018)\end{array}$ \\
\hline \multicolumn{2}{|l|}{ Some college } & $\begin{array}{l}0.181^{* * *} \\
(0.018)\end{array}$ & & $\begin{array}{l}-0.081^{* * *} \\
(0.019)^{*}\end{array}$ & & $\begin{array}{c}0.122^{\text {*** }} \\
(0.018)\end{array}$ \\
\hline \multicolumn{2}{|l|}{ College grad } & $\begin{array}{l}0.192^{* * *} \\
(0.024)\end{array}$ & & $\begin{array}{l}-0.182^{* * *} \\
(0.025)\end{array}$ & & $\begin{array}{l}0.167^{* * *} \\
(0.025)\end{array}$ \\
\hline \multicolumn{2}{|l|}{ Advanced degree } & $\begin{array}{l}0.302^{* * *} \\
(0.026)\end{array}$ & & $\begin{array}{l}-0.2633^{* * *} \\
(0.028)\end{array}$ & & $\begin{array}{c}0.258^{* * *} \\
(0.027)\end{array}$ \\
\hline fixed effects & yes & yes & yes & yes & yes & yes \\
\hline $\mathrm{N}$ & 45,656 & 45,656 & 17,121 & 17,121 & 22,362 & 22,362 \\
\hline $\mathrm{R}^{2}$ & 0.040 & 0.078 & 0.055 & 0.095 & 0.041 & 0.078 \\
\hline
\end{tabular}

Source: SIPP Gold Standard File linked to Social Security Administration and IRS administrative records.

Notes : Sample is all women who are either the SIPP householder or spouse of the householder, ages 60 to 64 at time of SIPP interview, and survive until age 70. College completion and marital status are measured at time of SIPP interview. In columns (1) and (2) outcome variable is equal to 1 for women who had annual administrative record earnings (combined wages and selfemployment) of at least the prevailing federal hourly minimum wage times 10 hours per week times 52 weeks per year. In columns (3) and (4) outcome variable is equal to 1 for women who had positive annual administrative record income from OASDI. In columns (5) and (6) outcome variable is 1 for women who had positive annual administrative record retirement income from either Form W-2P for years 1978 to 1990 or Form 1099-R for years 1995 to 2012. Sample is restricted to those with a Personal Identification Key (PIK) that allows linking to the administrative records. SIPP sample weights are adjusted to account for selection into having a PIK. For each SIPP panel we estimate a logit model for the presence of a PIK as a function of SIPP demographic characteristics and predict the estimated propensity score. We then take the SIPP sample weight and multiply it by the inverse of the estimated propensity score. Resulting weights are used in analysis.

Standard errors in parenthesis are clustered at the individual level. * denotes statistical significance at the $10 \%$ level; ** at the $5 \%$ level; $* * *$ at the $1 \%$ level. 
Table 3: Income Receipt and Percentiles by Cohorts of Women Age 65-69

\begin{tabular}{rcccccc}
\hline \hline & Cohort 1 & Cohort 2 & Cohort 3 & Cohort 4 & Cohort 5 & Cohort 6 \\
Income year & 1984 & 1989 & 1995 & 2000 & 2003 & 2007 \\
Birth year & $1916-1920$ & $1921-1925$ & $1927-1931$ & $1932-1936$ & $1935-1939$ & $1939-1943$ \\
\hline
\end{tabular}

Social Security Receipt

$\begin{array}{lllllll}\text { CPS } & 0.906 & 0.882 & 0.880 & 0.874 & 0.863 & 0.800 \\ \text { SIPP-Linked } & 0.886 & 0.877 & 0.876 & 0.889 & 0.890 & 0.831\end{array}$

Median Social Security Amount, cond. >0

$\begin{array}{lllllllllll}\text { CPS } & \$ 8,246 & \$ 7,589 & \$ & 8,920 & \$ & 9,262 & \$ & 9,827 & \$ 10,438 \\ \text { SIPP-Linked } & \$ 8,361 & \$ & 7,727 & \$ & 8,787 & \$ & 8,980 & \$ & 9,742 & \$ 10,452\end{array}$

Retirement Income Receipt

$\begin{array}{lllllll}\text { CPS } & 0.288 & 0.289 & 0.268 & 0.271 & 0.272 & 0.260 \\ \text { SIPP-Linked } & 0.233 & 0.323 & 0.399 & 0.404 & 0.435 & 0.454\end{array}$

Median Retirement Income Amount, cond. >0

$\begin{array}{lllllllllll}\text { CPS } & \$ 5,200 & \$ & 7,429 & \$ 7,305 & \$ 8,630 & \$ 8,668 & \$ 10,426 \\ \text { SIPP-Linked } & \$ & 4,934 & \$ & 6,801 & \$ & 6,951 & \$ 8,628 & \$ 11,132 & \$ 11,893\end{array}$

Household Income

25th percentile

$\begin{array}{llllll}\text { (1) CPS all sources } \quad \$ 18,368 & \$ 20,458 & \$ 20,810 & \$ 22,837 & \$ 21,893 & \$ 23,138\end{array}$

$\begin{array}{lllllll}\text { (2) CPS five sources } & -- & \$ 19,400 & \$ 19,933 & \$ 21,913 & \$ 21,210 & \$ 22,485\end{array}$

$\begin{array}{llllll}\text { (3) SIPP-linked admin } \quad-- & \$ 22,436 & \$ 23,235 & \$ 28,825 & \$ 26,063 & \$ 33,714\end{array}$

$\begin{array}{llllll}\text { Percent diff (3) / (2) } & 16 \% & 17 \% & 32 \% & 23 \% & 50 \%\end{array}$

50th percentile

$\begin{array}{lrrrrrr}\text { (1) CPS all sources } & \$ 33,029 & \$ 36,050 & \$ 35,520 & \$ 40,470 & \$ 39,453 & \$ 43,205 \\ \text { (2) CPS five sources } & -- & \$ 34,780 & \$ 34,238 & \$ 39,025 & \$ 38,310 & \$ 41,977 \\ \text { (3) SIPP-linked admin } & -- & \$ 38,689 & \$ 41,864 & \$ 50,774 & \$ 46,755 & \$ 60,939 \\ \text { Percent diff (3) / (2) } & & 11 \% & 22 \% & 30 \% & 22 \% & 45 \%\end{array}$


75th percentile

$\begin{array}{lllllll}\text { (1) CPS all sources } & \$ 55,963 & \$ 61,774 & \$ 59,896 & \$ 68,091 & \$ 69,011 & \$ 77,702\end{array}$

$\begin{array}{lllllll}\text { (2) CPS five sources } & -- & \$ 59,696 & \$ 58,007 & \$ 65,982 & \$ 67,367 & \$ 74,691\end{array}$

$\begin{array}{llllll}\text { (3) SIPP-linked admin } & -- & \$ 62,374 & \$ 67,065 & \$ 79,914 & \$ 76,049\end{array}$

\begin{tabular}{llllll} 
Percent diff $(3) /(2)$ & $4 \%$ & $16 \%$ & $21 \%$ & $13 \%$ & $27 \%$ \\
\hline
\end{tabular}

Sources: SIPP Gold Standard File linked to Social Security Administration and IRS administrative records and CPS ASEC.

Notes: Sample is all women who are either the householder or spouse of the householder, ages 65 to 69 at time of interview in either the SIPP or the CPS ASEC. Social security receipt is fraction of women with positive annual OASDI benefits either in the administrative records or in the CPS ASEC. Retirement income receipt is fraction of women with positive annual administrative record retirement income from either Form W-2P for years 1978 to 1990 or Form 1099-R for years 1995 to 2012 or positive amounts of retirement, survivor, or disability income outside of social security and VA benefits in the CPS ASEC. SIPP sample is restricted to those with a Personal Identification Key (PIK) that allows linking to the administrative records. SIPP sample weights are adjusted to account for selection into having a PIK. For each SIPP panel we estimate a logit model for the presence of a PIK as a function of SIPP demographic characteristics and predict the estimated propensity score. We then take the SIPP sample weight and multiply it by the inverse of the estimated propensity score. Resulting weights along with CPS ASEC sample weights are used in analysis. "CPS all sources" refers to total income in the CPS ASEC while "CPS five sources" includes only earnings, social security, SSI, interest and dividends, and retirement income, which are the same types of income available in the linked SIPP-admin data. Amounts are inflation adjusted using the CPI-U-RS and expressed in 2012 dollars. Total income amounts are unavailable for 1984. CPS ASEC retirement income for 1984 includes an estimate of survivor and disability income for that year which raises the rate by 7 percentage points. 
Table 4: Income of Retirement-Age Women by Years of Work Experience Between Ages 40 and 59: 2012

\begin{tabular}{|c|c|c|c|c|c|c|c|c|c|}
\hline \multirow{2}{*}{$\begin{array}{l}\text { Work Experience } \\
\text { Between Ages 40-59 }\end{array}$} & \multirow{2}{*}{$\begin{array}{c}\text { Distribution } \\
\text { of Sample }\end{array}$} & \multicolumn{2}{|c|}{$\begin{array}{l}\text { Own Retirement } \\
\text { Income Receipt }\end{array}$} & \multicolumn{2}{|c|}{ Median Own Income } & \multirow{2}{*}{$\begin{array}{c}\text { Percent } \\
\text { Difference } \\
\end{array}$} & \multicolumn{2}{|c|}{$\begin{array}{l}\text { Median Household } \\
\text { Income } \\
\end{array}$} & \multirow{2}{*}{$\begin{array}{c}\text { Percent } \\
\text { Difference }\end{array}$} \\
\hline & & CPS & Admin & CPS & Admin & & CPS & Admin & \\
\hline \multicolumn{10}{|l|}{ All Women } \\
\hline Work 0-5 Years & $17 \%$ & 0.108 & 0.154 & $\$ 9,974$ & $\$ 8,692$ & $-13 \%$ & $\$ 31,220$ & $\$ 39,120$ & $25 \%$ \\
\hline Work 6-10 Years & $11 \%$ & 0.163 & 0.272 & $\$ 12,056$ & $\$ 12,132$ & $1 \%$ & $\$ 46,406$ & $\$ 52,977$ & $14 \%$ \\
\hline Work 11-15 Years & $15 \%$ & 0.250 & 0.426 & $\$ 16,182$ & $\$ 18,863$ & $17 \%$ & $\$ 41,867$ & $\$ 52,693$ & $26 \%$ \\
\hline Work 16-20 Years & $58 \%$ & 0.377 & 0.598 & $\$ 26,020$ & $\$ 31,686$ & $22 \%$ & $\$ 53,875$ & $\$ 64,715$ & $20 \%$ \\
\hline $\mathrm{N}=3361$ & & & & & & & & & \\
\hline \multicolumn{10}{|l|}{ Married Women } \\
\hline Work 0-5 Years & $17 \%$ & 0.055 & 0.101 & $\$ 9,195$ & $\$ 7,684$ & $-16 \%$ & $\$ 44,339$ & $\$ 50,138$ & $13 \%$ \\
\hline Work 6-10 Years & $12 \%$ & 0.125 & 0.228 & $\$ 11,541$ & $\$ 11,717$ & $2 \%$ & $\$ 60,674$ & $\$ 64,551$ & $6 \%$ \\
\hline Work 11-15 Years & $14 \%$ & 0.186 & 0.353 & $\$ 13,632$ & $\$ 15,331$ & $12 \%$ & $\$ 58,597$ & $\$ 71,146$ & $21 \%$ \\
\hline Work 16-20 Years & $56 \%$ & 0.338 & 0.572 & $\$ 21,895$ & $\$ 28,916$ & $32 \%$ & $\$ 68,995$ & $\$ 82,609$ & $20 \%$ \\
\hline
\end{tabular}


Not Married Women (includes cohabitators)

$\begin{array}{lcccccrrrr}\text { Work 0-5 Years } & 15 \% & 0.204 & 0.250 & \$ 11,802 & \$ 10,231 & -13 \% & \$ 15,361 & \$ 15,211 & -1 \% \\ \text { Work 6-10 Years } & 9 \% & 0.247 & 0.371 & \$ 13,890 & \$ 14,227 & 2 \% & \$ 18,508 & \$ 22,119 & 20 \% \\ \text { Work 11-15 Years } & 16 \% & 0.343 & 0.530 & \$ 19,255 & \$ 23,075 & 20 \% & \$ 24,051 & \$ 30,812 & 28 \% \\ \text { Work 16-20 Years } & 60 \% & 0.435 & 0.637 & \$ 30,465 & \$ 34,781 & 14 \% & \$ 36,314 & \$ 41,629 & 15 \%\end{array}$

$\mathrm{N}=1329$

Source: CPS ASEC linked to administrative records.

Notes: Sample consists of women ages 65 to 69 in the 2013 CPS ASEC who are either the householder or the spouse of the householder. Years of work experience between ages 40 to 59 are calculated as the number of years where annual earnings (wages and self-employment combined) in the administrative records exceed the prevailing hourly federal minimum wage times 10 hours per week times 52 weeks per year. Marital status is determined as of the CPS ASEC interview date. CPS columns refer to amounts reported on the 2013 ASEC survey, while Admin columns refer to amounts after substituting values from administrative records. Admin sample is restricted to CPS respondents with a Personal Identification Key (PIK) that allows linking to the administrative records. CPS ASEC sample weights are adjusted to account for selection into having a PIK. For each year of the CPS ASEC we estimate a logit model for the presence of a PIK as a function of CPS ASEC demographic characteristics and predict the estimated propensity score. We then take the CPS ASEC sample weight and multiply it by the inverse of the estimated propensity score. Resulting weights along with CPS ASEC sample weights are used in analysis. 